\title{
Ergonomics and Employee Satisfaction with Special Reference to Selected Branches of Rajshahi Krishi Unnayan Bank
}

Dr. Mohammad Azizur Rahman ${ }^{* 1}$ Md. Zahid Hossain ${ }^{2}$ Dr. Mohammad Rafiul Azam Khan ${ }^{3}$

1. ${ }^{*}$ Associate Professor, Department of Management Studies, Begum Rokeya University, Rangpur. Bangladesh. Corresponding Author's E-mail: azizru07@gmail.com/ azizur.mgt@ brur.ac.bd

2. Associate Professor, Department of Marketing, Begum Rokeya University, Rangpur, Bangladesh. Email: zhbrur@gmail.com/zahid.mkt@brur.ac.bd

3. Associate Professor, Department of Management Studies, Begum Rokeya University, Rangpur, Bangladesh. Email: neeshar.bru@gmail.com, mrakhan@brur.ac.bd

Corresponding Author's Dr. Mohammad Azizur Rahman* E-mail: azizru07@gmail.com/ azizur.mgt@brur.ac.bd

\begin{abstract}
The study aims at examining the ergonomics practices in the banking sector of Bangladesh especially on Rajshahi Krishi Unnayan Bank (RAKUB) and strains to show the relationship between ergonomics and employee satisfaction in the workplace. This study conducted on the existing employees serving the said bank branches operating in Rangpur. The significance of ergonomics in the workstation was commenced in 1949 in the Ideas Bank in US. Ergonomics, a new design of applying sophisticated tools facilitates employees' performance and general productivity ensuring congenial work environment. A theoretical framework has been developed showing the dependent variable and independent variables were showed. The study confirmed that there is highly significant relationship between ergonomics factors and employee satisfaction withe help of Pearson Correlation Matrix. Employee satisfaction is very much important for earning profit and maximizing wealth of the bank. The study explored specific factors such as working tools, health, body posture, acoustics, working time, working environment and distinctly analyzed these factors while data collection. Data were collected through Likert's Five Point Scale and used SPSS software. For internal consistency and reliability test, used Cronbach's Alpha (.958) and KMO (.625>.5) test for quantifying observations in this study. The study identified six considerable factors having the direct relation with employee satisfaction. The study explored some specific delinquent in the practices of ergonomics in the banks and suggested for overcoming the challenges as well.
\end{abstract}

Keywords: Ergonomics, Satisfaction, Rajshahi Krishi Unnayan Bank (RAKUB ), Working Environment, Productivity etc.

\section{Introduction}

Studies have been shown that workplace environments characterized by intense heat, dim lighting, and congested works areas can be associated with stress and employee job satisfaction. This environment has many aspects like humidity systems, lighting, work area design, acoustic system and many more (www.ergoinc.com) [21] In this regard, in the process of designing a workstation, several factors especially ergonomic factors must be taken into consideration. The failure to implement the ergonomic principles at the workplaces can lead to emotional depression, physical exhaustive and declining productivity and products' quality and finally employee job dissatisfaction. It author defend as is the scientific discipline relating to human factors and ergonomics with comprehending of collaborations among human and other elements (Harshal, 2017) [9]. Extreme and constant exposure to stress might decrease a person's ability to perform at work and create work dissatisfaction. For this reason, this study should be accepted because its contributions are significant and able to convert manpower to be more productive and competitive. Furthermore, literary reviews show that there are very few studies in this field. Information on the application of ergonomics in developing countries where knowledge and awareness of the importance of 
ergonomic is still low and hard to find though a very interesting branch for ergonomic studies. Thus, the main objective of this research is to examine the most significant factor in the ergonomics practices in the workstation factors which affect the level of job satisfaction of RAKUB employees.

\section{Background and Operational Definitions of Ergonomics}

Ergonomics evolved in 1949 by the British Admiralty through an official meeting and accepted in 1950. 'Ergon' and 'Nomos' mean work and natural law concerned with scientific work discipline (Harshal, 2017) [9]. It is the study of human abilities and profiles influencing the design of work related equipment, systems, and jobs. Ergonomics accelerates functions; reduce work loadings and absenteeism, saving time and money 9 www.gamep.org/news-andresources). There is a functional relationship between ergonomics and satisfaction of employees. It is a design of office spaces with using appropriate sophisticated tools for operating the job efficiently and effectively and bringing the adjustable tools, better job environment lighting systems and concerning about the employee health issues (ergo.human.cornell.edu) [23].

\section{Types of Ergonomics}

1. Physical ergonomics: related to human functional, spiritual and physical activities.

2. Cognitive ergonomics: concerned with mental, perception, memory, reasoning which influence interactions among existing employees.

3. Organizational ergonomics: related to systems, structures, policies of human development

\section{Why Ergonomics?}

Ergonomics is the natural law of job which is workplace or our day to day lives (www.workpace.com) [22]. It can make job easier and workforce safer. Banking employees are to do their job with huge pressure. If the better condition may ensure in the station they feel well investing their work hard. Consequently, economic riskiness reduces and improves productivity, quality of customer service and engagement culture in the banking industries.

\section{Different Factors of Ergonomics}

In this study there are seven working tools, working environment, working time, lighting, health, acoustics and body postures are the factors of ergonomics have been considered.

\section{Ergonomics in Banking Sector}

The Ergonomics Ideas Bank bounces employer's admittance to philosophies that other employers already practice. Several were collected from companies with prevailing ergonomics packages, as well as from employers who contributed in L\&I-sponsored march missions (L*\& I, 2003() [12]. The current phase of the banking cycle appears to be driven by a recession of economic activity rather than financial suffering. Expressively, the financial institutions are among the biggest due to debt concerns. The global financial system has gone through structural variations. The global factors driving these changes are technological advances and computing external financial liberalization and organizational diversity in the corporate world. Expansion of financial activities and technology has redefined business models in a growing market-driven environment and changed the way banks conduct banking business. Setting up sophisticated tools banking industry has been drastic changes in all sections.

\section{Ergonomics impact in the workplace and quality of work in banking sector}

The impact or ergonomic workplace has an influence on employees work quality. As we can say, when a person is planning for lunch in restaurant he will not only look at the food but also the ambience of the place. Same is the case with the bank too, it must be the top rated 
bank but if the workplace is not comfortable or employee is having more health issues the productivity of individual employee will come down. Banking sector is a place where employees have to sit for long periods of time and be vigilant and they transact money. Office furniture must be designed with employees in mind, such as their chair, table, must be height adjustable. There is correlation between employee and the spacious in the office.

\section{Employee Contentment or Satisfaction}

Employee satisfaction is a word referred to define whether employees in the workplace are happy and satisfied with meeting their desires and needs (Schermerhorn, J.R.,2005) [14]. The purpose of many initiatives is to ensure employee satisfaction, a factor of employee motivation, achievement of goals and positive employee morale in the job place. Satisfaction depends on banking policies, treatment, HDR environment, team work, promotion, possibilities of advancement, evaluation of taking challenging job performance and recognition. It is the most important factor of the banking industry since banks has to tackle all kinds of human resources in the context of global financial business. A good ergonomics practice is enormously beneficial to both the employer and employee. It's is a very costeffective way to increase performance, health and wellness, and happiness. It can be expected the better results for corporations that are fully committed to the ergonomic restructure of their workplace and the establishment of an active ergonomics program. Hiring a good agent is much more affordable for employers than hiring a replacement.

\begin{tabular}{|c|c|}
\hline $\begin{array}{c}\text { Independent Variables } \\
\text { Working Tools, Working Environment, } \\
\text { Body Posture, Working Time, Health }\end{array}$ &
\end{tabular} $\begin{gathered}\text { Dependent Variable } \\
\text { Employee Satisfaction }\end{gathered}$

\section{Figure 1: Theoretical Framework}

\section{Research Objectives}

The main goal of the study is to observe the effect of ergonomics on employee satisfaction in banking sector of Bangladesh especially on RAKUB. For confirming the basic goal the following specific objectives are highlighted:

- to state an overview on ergonomics;

- to detect employee knowledge and perception regarding ergonomics;

- to show the relationship between ergonomics and employee satisfaction; and

- to investigate specific issues and make recommendations in connection to ergonomics practices.

\section{Literature Review}

To help relieve tension, stress and precise posture for improved health, ergonomists consider some important key factors (Elizabeth Chacko, 2014) [6]. These key factors may include how a person sits, stands or moves in an area. It will also include the length of time for the activities. The range of motion and how people move in general are also taken into consideration. Ergonomists attempt to find out which situations put more pressure on the body and how they can relieve from the anxiety. Ergonomics studies exist to help improve people's working career. With the help of applied techniques, people have set up their work is easier and they are able to relax at the end of the day and on time. The application of 
ergonomics improves the overall quality of life of most people. Workplace is becoming one of the assessing points for the branding (www.workpace.com) [24]. As we earlier would say work place ethics is mandatory (Elizabeth Chacko, 2014) [6]. The "quality movement" strongly emphasizes the participation of employees in the development and improvement of their own work activities and day-to-day production activities. From this perspectives, the quality and developmental work, is conducive to improved working conditions and ergonomics. Ergonomics is a type of science that specifically emphases on creating an environment where people feel the least stress. Further, the commencement of development work has been obtained from a theoretical point of view which is consistent with the improvement of the characteristics representing good and fruitful work. The study of ergonomics doesn't just stop at how good the furniture and fixtures are. But above that, the stress level too is taken into consideration. In this study survey is conducted of employees working in banks irrespective of Private or Public Banks. The objective of the investigation is to know the importance of ergonomics in the work place and impact of technically designed tools on the quality of work performed by the employee. Workstation design can have a large impact on health. Uphill struggle are being made to endorse an environment in which physical condition and safety of employ should be given key significance (Khan, Farooqui, \& Omar, 2012) [11]. Ergonomics is considered as the discipline to optimize the association between environment and the person where the concern to assemble things at the workstation. The competency of the employer is directly related to the ergonomics. The application to design a place of work as personnel, use of tools and the overall situation is called ergonomic design. It focuses on the compatibility of objects and environment with the humans using them. Incidents of work stress contribute to the ratio of job dissatisfaction, burnout and retention in many organizations (Makhbul, 2011) [16]. As with most literature reviews, the poor ergonomics workstation environment is a major contributor to stressful outcomes such as psychological complaints and intensions to leave.

From the above reviews and context of the different studies researchers found that practices of ergonomics are in the various organizations. The present study has given the concentration on the relations between ergonomics and employee satisfaction in the banking sector especially in RAKUB.

\section{Methodology}

\section{Research Design}

The convergent design (Creswell \& Clark, 2018) [4] as been applied for gathering information and analyzing qualitative and quantitative data. 60 (Sixty) respondents for survey are selected through simple random sampling (SRS) techniques by means of lottery. RAKUB in Rangpur there are 28 branches excluding Zonal and Divisional Offices whereas 171 employees are serving holding various positions in the organization structure (Zonal Office, 2020) [18]. This study is conducted on employees ( 33\%) of 10 branches $(\sim 36 \%)$ selected (Cochran, 1977) [2].

\section{Sample Size}

Subjective sampling method has been taken to choose the number of branches as well employees as respondents. In this regards 60 respondents has been selected from 10 branches of RAKUB operating in Rangpur.

\section{Sources of Data}

Both primary sources such as interview and secondary namely annual reports, websites, different articles, books, periodicals of the banks have been used to collect data. Primary data collection process was completed by distributing questionnaires. The questionnaires were developed by modifying a number of questions related to ergonomics workstation factors and 
employee job satisfaction used in previous studies. There were also new questions created specifically to achieve the objectives of this investigation in the context of RAKUB. Every item uses a 5-Point Likert's Scales i.e. (5) strongly agree, (4) agree, (3) moderately agree, (2) disagree and (1) strongly disagree and question use yes or no format for calculating direct percent of employee.

\section{Research Validity and Reliability}

The pilot and final survey analysis manufactured the Cronbach's Alpha 0.768 and 0.805 respectively which confirmed the scale reliability and internal consistency of the research tool. Furthermore, content validity was also verified. Therefore, it can be said that, this investigation is valid and reliable.

\section{Statistical Test Method}

Mean, reliability statistics (George and Mallery, 2003) [8], Chi-square test for hypotheses test, factor analysis have been done with the help of SPSS software.

Findings and Discussions

Table 1: Demographic Shape of the Respondents (RAKUB Employees)

\begin{tabular}{|l|l|l|}
\hline Variables & Particulars & Frequency and Percent \\
\hline \multirow{4}{*}{ Agender } & Male & $35(58 \%)$ \\
\cline { 2 - 3 } & Female & $25(42 \%)$ \\
\hline \multirow{5}{*}{ Educational qualifications } & from 20-30 & $20(33.33 \%)$ \\
\cline { 2 - 3 } & from 30-40 & $15(25 \%)$ \\
\cline { 2 - 3 } & from 50-60 & $25(42.17 \%)$ \\
\cline { 2 - 3 } & B.S.Com. & $5(8 \% 0$ \\
\cline { 2 - 3 } & Honors & $5(8 \%)$ \\
\cline { 2 - 3 } & Master & $25(42 \%)$ \\
\hline \multirow{5}{*}{$\begin{array}{l}\text { Job position } \\
\text { in the workplace }\end{array}$} & Manager & $25(42 \%)$ \\
\cline { 2 - 3 } & Officer & $10(17 \%)$ \\
\cline { 2 - 3 } & Cashier & $35(58 \%)$ \\
\cline { 2 - 3 } & Supervisor & $10(17 \%)$ \\
\hline \multirow{5}{*}{$\begin{array}{l}\text { Familiar with ergonomics } \\
\text { RAKU uses comfortable }\end{array}$} & Yes & $5(8 \%)$ \\
\cline { 2 - 3 } & No & $7(12 \%)$ \\
\hline \multirow{5}{*}{ Working chair and desk are } & Highly agree & $53(88 \%)$ \\
\cline { 2 - 3 } & Agree & $10(17 \%)$ \\
\cline { 2 - 3 } & Moderately agree & $20(33 \%)$ \\
\cline { 2 - 3 } & Disagree & $5(8 \%)$ \\
\cline { 2 - 3 } & Highly disagree & $25(42 \%)$ \\
\cline { 2 - 3 } & Agree & $0(0 \%)$ \\
\cline { 2 - 3 } & Moderately agree & $5(8 \%)$ \\
\cline { 2 - 3 } & Disagree & $5(8 \%)$ \\
\cline { 2 - 3 } & Highly disagree & $5(8 \%)$ \\
\hline
\end{tabular}




\begin{tabular}{|c|c|c|}
\hline \multirow[t]{4}{*}{ adjustable } & Agree & $5(8 \%)$ \\
\hline & Moderately agree & $15(25 \%)$ \\
\hline & Disagree & $25(42 \%)$ \\
\hline & Highly disagree & $10(17 \%)$ \\
\hline \multirow{5}{*}{$\begin{array}{l}\text { Working environment and } \\
\text { comfortable for job }\end{array}$} & Highly agree & $5(8 \%)$ \\
\hline & Agree & $10(17 \%)$ \\
\hline & Moderately agree & $15(25 \%)$ \\
\hline & Disagree & $25(42 \%)$ \\
\hline & Highly disagree & $5(8 \%)$ \\
\hline \multirow{5}{*}{$\begin{array}{l}\text { Repetitive movement longer } \\
\text { period of time }\end{array}$} & Highly agree & $10(17 \%)$ \\
\hline & Agree & $20(33 \%)$ \\
\hline & Moderately agree & $5(8 \%)$ \\
\hline & Disagree & $15(25 \%)$ \\
\hline & Highly disagree & $10(17 \%)$ \\
\hline \multirow[t]{5}{*}{ Body posture } & Highly agree & $5(8 \%)$ \\
\hline & Agree & $25(42 \%)$ \\
\hline & Moderately agree & $5(8 \%)$ \\
\hline & Disagree & $20(34 \%)$ \\
\hline & Highly disagree & $5(8 \%)$ \\
\hline \multirow{5}{*}{$\begin{array}{l}\text { Work does not make me } \\
\text { physically tired }\end{array}$} & Highly agree & $10(17 \%)$ \\
\hline & Agree & $20(33 \%)$ \\
\hline & Moderately agree & $10(17 \%)$ \\
\hline & Disagree & $15(25 \%)$ \\
\hline & Highly disagree & $5(8 \%)$ \\
\hline \multirow{5}{*}{$\begin{array}{l}\text { Feeling satisfied with the } \\
\text { working hour }\end{array}$} & Highly agree & $5(8 \%)$ \\
\hline & Agree & $25(42 \%)$ \\
\hline & Moderately agree & $5(8 \%)$ \\
\hline & Disagree & $15(15 \%)$ \\
\hline & Highly disagree & $10(17 \%)$ \\
\hline \multirow{5}{*}{$\begin{array}{c}\text { Happy for work breaking } \\
\text { time }\end{array}$} & Highly agree & $10(17 \%)$ \\
\hline & Agree & $25(41 \%)$ \\
\hline & Moderately agree & $5(8 \%)$ \\
\hline & Disagree & $10(17 \%)$ \\
\hline & Highly disagree & $10(17 \%)$ \\
\hline
\end{tabular}

Source: Field Survey

From the above Table 1 it is inferred that 35 or $58 \%$ of the employees fall under male sex and rest of 25 or $42 \%$ are female out of total 60 sample size and $28 \%$ of the male employees fall under the age cluster of 20-30 years, $28 \%$ of the male employees fall under the age group of 30-40 years and $44 \%$ of employees fall under the age range of 50-60 year. About $40 \%$ of the male employees fall under the age between of 20-30 years, $20 \%$ of the male employees fall under the age sort of 30-40 years and $40 \%$ of employees within the age group of 40-5 0 
years are found. The educational qualification of the respondents were got that about $8 \%$ employees education levels in HSC, of $8 \%$ graduate or B.Com, of $46 \%$ are honors, of $35 \%$ are Masters and rest of 3\% are M.Phil. The employee job positions were 17\% of manager, $17 \%$ cashier, $58 \%$ officer and $8 \%$ are supervisor respectively. Most of the employees were not well informed regarding the ergonomics in their workplace. Even $88 \%$ of the respondents replied negatively and directly in case of the question of ergonomics and remaining 12\% replied positively. In case of using modern tools and technology in the job station it has been found that $17 \%$ of the employees were strongly agreed, 20 or $33 \%$ agreed, 5 or $8 \%$ are moderately agreed, 25 or $42 \%$ are disagreed and 0 or $0 \%$ strongly disagreed respectively. In the question of comfortable and desk assists the work efficiently it was inferred that 5 or $8 \%$ of the employees were intensely agreed, 15 or $25 \%$ agreed, 10 or $17 \%$ are moderately agree, 25 or $42 \%$ disagreed and 5 or $8 \%$ of the existing employees strongly disagreed. The employees replied in terms of setting adjustable chair and desk in the RAKUB whereas, $8 \%$ of the employees were highly agreed, 5 or $8 \%$ agreed, $25 \%$ moderately agreed, $42 \%$ disagreed and remaining $17 \%$ of existing toughly disagreed out of 60 employees of the bank. It is found that the maximum number $42 \%$ of employees are disagreed in case of working hour. That means the existing employees are satisfied in case of working environment and flexibility of time.

\section{Overall Empirical Study Result}

As the first step, the reliability and internal reliability of the variables are examined. The overall Cronbach's Alpha of all the 17 items under study is found to be .958 as shown Table 4.48 which means that the data set has relatively good internal uniformity.

Table 2 : Overall Reliability Test Statistics

\begin{tabular}{|l|l|}
\hline Cronhach's Alpha & No. of Items \\
\hline .958 & 17 \\
\hline
\end{tabular}

The consistency analysis (Table 2) of the independent and the dependent variable are given below which is shown that Cronbach's Alpha coefficient is relatively good for all the 6 independent and dependent variable (employee satisfaction) including 17 items.

Table 3: Cronbach's Alpha Values of all Variables

\begin{tabular}{|c|c|c|c|c|}
\hline SL & Variable Name & Items & Cronbach's Alpha & Internal Consistency \\
\hline 1 & Working tools & 3 & .898 & \multirow{7}{*}{$\begin{array}{l}\text { Excellent and data are fit } \\
\text { and reliable for factor } \\
\text { analysis } \\
\text { (George \& Mallery 2003) } \\
\text { [8] }\end{array}$} \\
\hline 2 & Working Environment & 2 & .960 & \\
\hline 3 & Body Posture & 2 & .880 & \\
\hline 4 & Working Time & 3 & .883 & \\
\hline 5 & Health & 2 & .910 & \\
\hline 6 & Acoustic & 2 & .558 & \\
\hline 7 & Employee Satisfaction & 3 & .972 & \\
\hline
\end{tabular}

\section{Descriptive Statistics}

The results of Descriptive Statistics of Working Tools, Working Environment, Body Posture, Working Time, Health, Acoustics and Employee Satisfaction are given below-

Table 4: Variables and Mean Values

\begin{tabular}{|l|l|l|l|}
\hline Variables & Question & Mean & Average Mean \\
\hline A. Working tools & 1. Modern Tools & 3.250 & $\mathbf{2 . 8 6 1}$ \\
\hline
\end{tabular}




\begin{tabular}{|c|c|c|c|}
\hline & 2. Comfortable Chair & 2.833 & \\
\hline & 3. Adjustability & 2.500 & \\
\hline \multirow[t]{2}{*}{ B. Working environment } & 4.Comfortable For Work & 2.750 & \multirow[t]{2}{*}{2.625} \\
\hline & 5. Repetitive Work & 2.500 & \\
\hline \multirow[t]{2}{*}{ C. Body posture } & 6. Comfortable Posture & 3.083 & \multirow[b]{2}{*}{2.917} \\
\hline & 7. Physically Tired & 2.750 & \\
\hline \multirow[t]{3}{*}{ D. Working time } & 8. Working Hour & 3.00 & \multirow{3}{*}{$\begin{array}{l}3.306 \\
\text { (the highest) }\end{array}$} \\
\hline & 9. Longer Time Work & 3.670 & \\
\hline & 10. Braking Time & 3.250 & \\
\hline \multirow[t]{2}{*}{ E. Health } & 11. Irregular Sleep & 2.583 & \multirow[t]{2}{*}{2.500} \\
\hline & 12. Waist Pain & 2.417 & \\
\hline \multirow[t]{2}{*}{ F. Acoustics } & 13. Sound Pollution level & 2.750 & \multirow[t]{2}{*}{2.625} \\
\hline & 14. Action for Sound Pollution & 2.500 & \\
\hline \multirow[t]{3}{*}{ G. Employee satisfaction } & 15. Like this Organization & 3.000 & \multirow[t]{3}{*}{$2.667<3.0$} \\
\hline & 16. Current Job & 2.500 & \\
\hline & 17. Tell to Other & 2.500 & \\
\hline
\end{tabular}

\section{Chart 1: Results of Mean Values of all Variables}

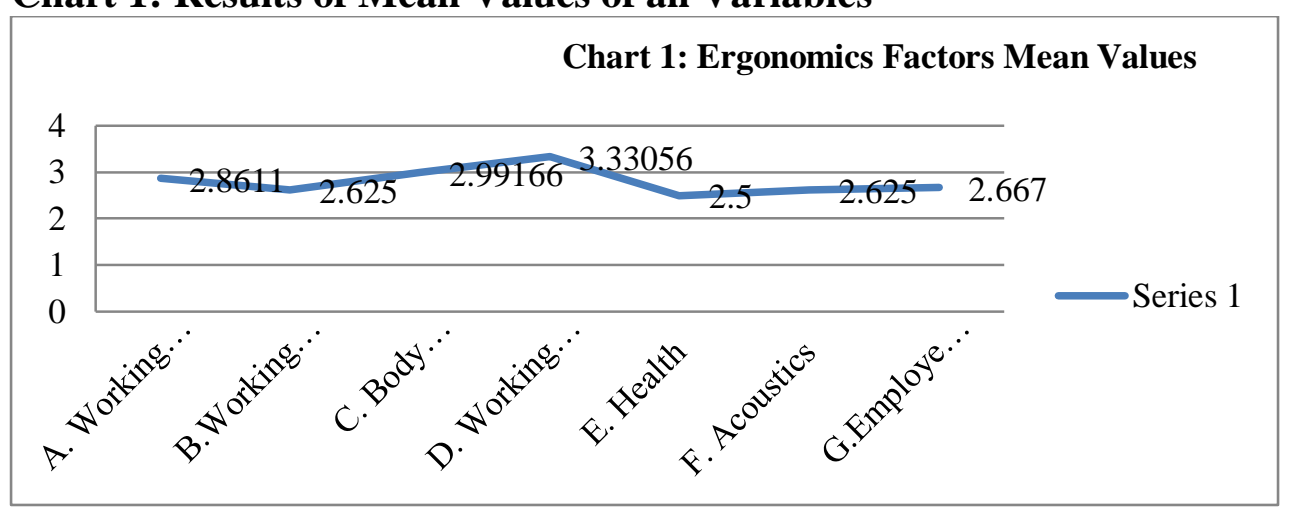

(A) Average mean test result of working tools is 2.861and our average mean result is 3 . Therefore, RAKUB does have the problems regarding working tools. (B) Average mean value of working environment is 2.625 and average mean result is 3 . Hence, RAKUB does have the working environment problem. (C) Average mean test result of body posture is 2.917 and our average mean result is 3. So, Employee of RAKUB has body posture adjusting problem. (D) Average mean test result of working time is 3.306 and our average mean result is 3. Consequently, RAKUB has not working time problem. (E) Average mean test result of health is 2.500 and our average mean result is 3 . Hence, the employee of RAKUB has health problem. (F) Average mean test result of acoustics is 2.625 and our average mean result is 3 . So, RAKUB has acoustics problem. (G) Average mean results of employee satisfaction is $2.667<3.0$. Therefore, the employees of RAKUB are not satisfied in ergonomics practice level.

\section{Constructing the Null Hypotheses $\left(\mathrm{H}_{0}\right)$}

$H_{01}$ : There is no association between working tools and employee satisfaction.

$H_{02}$ : There is no connection between working environment and employee satisfaction.

$H_{03}$ : There is no relationship between body posture and employee satisfaction. 
$H_{04}$ : There is no relationship between working time and employee satisfaction.

$H_{05}$ : There is no relationship between health and employee satisfaction.

$H_{06}$ : There is no association between acoustics and employee satisfaction.

Table 5 : Correlation between Working Tools and Employee Satisfaction

\begin{tabular}{|l|l|l|l|}
\hline \multicolumn{2}{|c|}{} & Working Tools & Employee Satisfaction \\
\hline \multirow{2}{*}{ Working Tools } & Pearson Correlation & 1 & $.303^{* *}$ \\
\cline { 2 - 4 } & Sig. (2-tailed) & & .000 \\
\hline \multirow{2}{*}{ Employee Satisfaction } & Pearson Correlation & $.303^{* *}$ & \\
\cline { 2 - 4 } & Sig. (2-tailed) & .000 & \\
\hline \multirow{2}{*}{$* *$ Correlation is significant at the 0.01 level (2-tailed). } & \\
\hline
\end{tabular}

The working tools has a significant relationship $(p<0.01)$ with employee satisfaction $(r=.303)$. Therefore, null hypothesis $\left(H_{01}\right)$ is sustained (Table 5). Consequently, there is a medium relationship between working tools and employee satisfaction.

Table 6: Correlation between Body Posture and Employee Satisfaction

\begin{tabular}{|l|l|l|l|}
\hline \multicolumn{2}{|c|}{} & Working Environment & Employee Satisfaction \\
\hline \multirow{2}{*}{$\begin{array}{l}\text { Working } \\
\text { Environment }\end{array}$} & Pearson Correlation & 1 & $.107^{* *}$ \\
\cline { 2 - 4 } $\begin{array}{l}\text { Employee } \\
\text { Satisfaction }\end{array}$ & Sig. (2-tailed) & & .244 \\
\hline & Pearson Correlation & $.107^{* *}$ & \\
\cline { 2 - 4 } *. Correlation is significant at the 0.01 level (2-tailed). & $.244(p>.01)$ & \\
\hline
\end{tabular}

The Table 6 shows that working tools has a relationship $(p>0.01)$ with the employee satisfaction $(r=.107)$. Hence, the null hypothesis is accepted $\left(H_{02}\right)$. Consequently, it can be said that there is no relationship between working environment and employee satisfaction

Table 7: Correlation between Body Posture and Employee Satisfaction

\begin{tabular}{|l|l|l|l|}
\hline \multicolumn{2}{|c|}{} & Body Posture & Employee Satisfaction \\
\hline Body Posture & Pearson Correlation & 1 & $.336^{* * *}$ \\
\cline { 2 - 4 } & Sig. (2-tailed) & & .000 \\
\hline \multirow{2}{*}{ Employee Satisfaction } & Pearson Correlation & $.336^{* * *}$ & \\
\cline { 2 - 4 } & Sig. (2-tailed) & .000 & \\
\hline \multirow{2}{*}{$* *$. Correlation is significant at the 0.01 level (2-tailed). } & \\
\hline
\end{tabular}

The above Table 7 results that body posture has a significant relationship $(p<0.01)$ with the employee satisfaction $(r=.336)$. Null hypothesis $\left(H_{03}\right)$ is rejected. Hence, there is medium relationship between body posture and employee satisfaction.

Table 8: Correlation between Working Time and Employee Satisfaction

\begin{tabular}{|l|l|l|l|}
\hline \multicolumn{2}{|c|}{} & Working Time & Employee Satisfaction \\
\hline Working Time & Pearson Correlation & 1 & $.444^{* * *}$ \\
\cline { 2 - 4 } & Sig. (2-tailed) & & .000 \\
\hline Employee Satisfaction & Pearson Correlation & $.444^{* * *}$ & \\
\cline { 2 - 4 } & Sig. (2-tailed) & .000 & \\
\hline \multirow{2}{*}{$* *$. Correlation is significant at the 0.01 level (2-tailed). } & \\
\hline
\end{tabular}

The Table 8 showing that Working time has a significant relationship $(p<0.01)$ with the employee satisfaction $\left(r=.444^{* *}\right)$. In this case, null hypothesis $\left(H_{04}\right)$ is not sustained. Hence, there is medium relationship between working time and employee satisfaction. 
Table 9: Correlation between Health and Employee Satisfaction

\begin{tabular}{|c|c|c|c|}
\hline & Health & Employee Satisfaction \\
\hline \multirow[t]{2}{*}{ Health } & Pearson Correlation & 1 & $.112^{* * *}$ \\
\hline & Sig. (2-tailed) & & .000 \\
\hline \multirow[t]{2}{*}{ Employee Satisfaction } & Pearson Correlation & $.112^{* * *}$ & \\
\hline & Sig. (2-tailed) & .000 & \\
\hline
\end{tabular}

The Table 9 shows that health has a relationship $(p<0.01)$ with the employee satisfaction $(r=.112)$. Here, null hypothesis $\left(H_{05}\right)$. Therefore, it can be said that there is a small relationship between health and employee satisfaction.

Table 10: Correlation between Acoustics and Employee Satisfaction

\begin{tabular}{|l|l|l|l|}
\hline \multicolumn{2}{|c|}{} & Acoustics & Employee Satisfaction \\
\hline Acoustics & Pearson Correlation & 1 & $.193^{* * *}$ \\
\cline { 2 - 4 } & Sig. (2-tailed) & & .035 \\
\hline \multirow{2}{*}{ Employee Satisfaction } & Pearson Correlation & $.193^{* *}$ & \\
\cline { 2 - 4 } & Sig. (2-tailed) & .035 & \\
\hline \multirow{2}{*}{$* *$. Correlation is significant at the 0.01 level (2-tailed). } & \\
\hline
\end{tabular}

The Table 10 resulting that acoustics does a significant relationship $(p<0.01)$ with the employee satisfaction $\left(r=.193^{*}\right)$. Here, $H_{06}$ is not confirmed. Now it can be said that there is a small relationship between acoustics and employee satisfaction.

\section{Suggestions}

$\checkmark$ RAKUB may arrange workshops, seminars, and training programs to increase ergonomics knowledge among the employees. Recently this bank has taken the initiatives for practicing ergonomics in its working environment.

$\checkmark$ RAKUB can provide ergonomics chairs and desks that are adjustable and comfortable for doing work. Ergonomic chair reduces employee body movement and builds work efficiency.

$\checkmark$ Work environment or work station design is important for employee satisfaction. Thus, RAKUB should be integrated into workstation design, when most employees feel that RAKUB's work environment is not good.

$\checkmark$ RAKUB must pay attention to the health problems of the employees. Most employees have regular sleep problems or they experience pain in their back and spine. Health problems are related to employee satisfaction. Therefore, RAKUB should introduce ergonomic practices to reduce employee health risks.

$\checkmark$ Noise issue can create work stress and it affects employee satisfaction. Thus, RAKUB may adopt a policy to reduce noise pollution in the workplace, when most employees feel that noise in the workplace is within a normal range and RAKUB does not to take any steps to reduce such kind of problems.

\section{Conclusion}

Employees in the banking sector need ergonomics practice to adapt to the technical equipment and to adapt their bodies to work chairs and desks. In addition, it brings benefits to the employer. This research has suggested the theoretical aspects in the RAKUB's work station which has a direct relation to the present employee satisfaction and finally results the sustainable customer satisfaction. Consequently this effect creates the benefits for the bank. Now in this modern edge, the banking sector has been becoming more modern day by day. Thus, bank employees need to respond quickly to their customers. To be active and energetic the employee must have a proper working condition. There are various reasons for 
ergonomics related to employee motivation. Therefore, employers should consider these issues to satisfy their employees. This present study found various problems related to ergonomics and tried to give some recommendations for the recovery of this issue. This study has been carried out only on RAKUB. Furthermore studies do have a lot of opportunity for the policy makers as well as academicians relating to other organizations.

\section{Acknowledgement}

The researchers would like to express gratitude to Mr. Md. M. Alam, AD, Bangladesh Bank, Rangpur Office for cooperating in collecting information and for acknowledging his hard work in this regard.

\section{References}

[1] Alam, M. (2016). Internship Report. Department of Management Studies, Begum Rokeya University, Rangpur.

[2] Cochran, W. G. (1977). Sampling Techniques. New York: John Wiley \& Sons.

[3] Cochrane, A. (2007). Understanding Urban Policy: A Critical Approach. Malden, MA: Blackwell Publishing

[4] Creswell, J. W., \& Clark, V. L. (2018). Designing and Conducting Mixed Methods Research (3rd ed.). California: SAGE Publications, Inc.

[5] Desai, Jigna. (2020). A Study on Learning Organization with Reference to Employee Engagement, Retention and Job Satisfaction in Industries. Maharaja Sayajirao University of Baroda (India), ProQuest.

[6] Elizabeth Chacko,( 2014). Human Adaptation to Shift Work in Improving Health, Safety and Productivity. Pritchard (B. 2005 -10) Stress and Cancer. Toronto: Hogrefe.

[7] Elo, A., Ervasti, J., Kuosma, E., \& Mattila, P. (2008). Evaluation of an organizational stress management program in a municipal public works organization. Journal of Occupational Health Psychology, 13(1), 10-23. doi: 10.1037/1076-8998.13.1.10.

[8] George, D., \& Mallery, P. (2003). SPSS for Windows step by step: A simple guide and reference 11.0 update $\left(4^{\text {th }}\right.$ ed.). Boston: Allyn \& Bacon

[9] Harshal, T. Pandve, (2017). Historical Milestones of Ergonomics Frome Ancient Human to Modern Human. Journal of Ergonomics, 07 (04). DOI:10.4172/2165-7556.1000e169

[10] Jose' Orlando Gomes, D.Sc, (2000). Human Factors and Ernonomics for a Better Life for Everyone. International Ergonomics Association Executive Council, August 2000. Retrieved fromhttps://ergo.human.cornell.edu/DEA3250Flipbook/DEA3250notes/ergorigin.html

[11] Khan, A. A., Farooqui, S. I., \& Omar, Z. (2012). The Association of Sitting Posture and Cervicogenic Pain among the Students of Physical Therapy. Pakistan Journal of Rehabilitation, 1(1), 28-31.

[12] L \& I, (2003), from https://www.ehstoday.com/archive/article/21908224/washingtonsergonomics-ideas-bank-debuts.

[13] Ranjit Vasant Power, S. B. Patil, T. R. Power, P. S. Bandgar (2021). Assessment of farmers' knowledge and perception towards the usage of sugarcane trash and environmental safety. Research Square Platform LLC.

[14] Schermerhorn, J.R., J.G. Hunt \& Osborn, R.N. (2005). Organizational Behavior ( 9th ed.) United States of America: John Wiley \& Sons, Inc.

[16] Zafir Mohd Makhbul, Syed Shah Alam, Shaza Marina Azmi, and Norliza Abu Talib (2011). Ergonomics and Work Stress Issues in Banking Sector. Australian Journal of Basic and Applied Sciences, 5(9): 1301-1309, 2011 ISSN 1991-8178. retrieved from http://ergoplus.com/workplace-ergonomics-benefits.

[17] www.rakub.org.bd 
[18] Zonal Office, RAKUB, Rangpur, Bangladesh/ Annual Reports of RAKUB.

[19] www.ergoinc.com/articles/ergonomics-not-buzzword-bottom-line-fact

[20] www.ergoinc.com/articles/solving-white-collar-pain-problems.

[21] www.gamep.org/news-and-resources/articles-and-white-papers/protecting-employeesby-making-your-workplace-more-ergonomic.

[22] www.reliableplant.com/Read/225/ergonomics-workplace

[23] www.ergo.edu.au/cprc/docs/Reducing_Sitting_Workplace_Summary.pdf

[24] www.workpace.com/assets/Uploads/White-Papers/Wellnomics-white-paper-Theproductivity-benefits-of-office-ergonomics-interventions.pdf 